\title{
INTEGRATION OF BIO-ETHICAL PRINCIPLES AND REQUIREMENTS INTO EUROPEAN UNION STATUTES, REGULATIONS AND POLICIES
}

\author{
Paul T. Schotsmans*
}

\begin{abstract}
This paper stresses the goals of the European Society for Philosophy of Medicine and Healthcare (ESPMM): to stimulate and promote the development and methodology in the field of philosophy of Medicine and Healthcare; to be a center for European scholars in this field; to promote international contact between members of the various countries in and outside Europe. It also concentrates on legal and regulatory bodies with regard to bioethics, overlooks the European bioethics tradition and the physician-patient relationship strengthening the solidarity concept.
\end{abstract}

Key words: biomedical research, human rights, integrity and dignity, solidarity

\section{INTEGRACIÓN DE PRINCIPIOS Y REQUERIMIENTOS BIOÉTICOS EN LOS ESTATUTOS, REGULACIONES Y POLÍTICAS DE LA UNIÓN EUROPEA}

Resumen: Este artículo acentúa las metas de la Sociedad Europea para la Filosofía de la Medicina y el Cuidado de la Salud: estimular y promover el desarrollo y la metodología en el campo de la filosofía de la medicina y el cuidado de la salud; ser un centro para los investigadores en este campo; y promover el contacto internacional entre los miembros de los países dentro y fuera de Europa. Asimismo, se concentra en temas legales y reguladores, y da una mirada a la tradición europea y a la relación médico-paciente, deteniéndose en el concepto de solidaridad.

Palabras clave: investigación biomédica, derechos humanos, integridad y dignidad, solidaridad

\section{INTEGRAÇÃO DE PRINCÍPIOS E EXIGÊNCIAS BIOÉTICAS NOS ESTATUTOS, REGULAMENTOS E POLÍTICAS DA UNIÃO EUROPEIA}

Resumo: Este artigo centua as metas da sociedade europeia para a filosofia da medicina e o cuidado da saúde: estimular e promover o desenvolvimento e a metodologia no campo da filosofia da medicina e no cuidado da saúde. Ser um centro para os pesquisadores neste campo e promover o contato internacional entre os membros dos países dentro e fora da Europa. Desta forma, se concentra em temas legais e regulatórios e também analisa a tradição européia da relação médico-paciente, detendo-se no conceito de solidaridade.

Palavras chaves: pesquisa biomédica, direitos humanos, integridade e dignidade, solidariedade

* BIBAC Member, Professor of Philosophy, University of Leuven Correspondence: Paul.Schotsmans@med.kuleuven.ac.be 


\section{Introduction}

Describing bioethics in Europe is impossible without honoring the founding fathers of bioethics. Several eminent bio-ethicists have to be mentioned, like Edouard Boné (Brussels, Belgium), Maurice de Wachter (Montreal, Canada and Maastricht, Netherlands), Richard Nicholson (London, U.K.), Nicole Léry (Lyon, France), Patrick Verspieren (Paris, France) and -even more than all the others- Francesc Abel (Barcelona, Spain). On the occasion of his election as a full member of the Royal Academy of Medicine of Catalonia, F. Abel s.j. started with a description of the early beginnings of bioethics: "Biomedical advances and new technologies caused such bewilderment - not to say fear-that doctors and biologists understandably became interested in clarifying concepts such as what is good, who has the authority to decide what is good and what is not good, and on what this authority is based. They also began searching for ethical decision-making criteria which could be broadly applicable. A group of doctors and researchers at the Johns Hopkins Hospital in Baltimore, Maryland, began meeting almost spontaneously to discuss these and similar questions under the leadership of Dr. André Hellegers (originally from Holland). At the same time and with the same purpose, other groups of university professors began meeting in Hastings-onHudson, a small town in New York, and at the University of Wisconsin Medical School in Madison. Similar meetings no doubt took place in other parts of the United States [...] I arrived at the Kennedy Institute at the beginning of 1972..." And he continues: "The Kennedy Institute, the Hastings Center, Barcelona's Institut Borja and Montreal's Institute of Bioethics were the four leading institutes in the earliest days of bioethics, and the Hospital de Sant Joan de Déu's Committee for Health Care Ethics was the first in Spain and probably, all of Europe ${ }^{1}$ ".

F. Abel s.j., Bioethical Dialogue in the Perspective of the Third Millennium, Barcelona, May 9th, 1999, 12; 17-18.
This makes clear that bioethics in Europe started mainly in the South (cf. also the influence of the Centers in Lyon with Nicole Léry and in Paris with Patrick Verspieren). On the worldwide level, however, the "start" of bioethics must be sought in the U.S.A. This happened in the beginning of the seventies of the twentieth century, while Europe only followed in a really structural way in the middle of the eighties. The Anglo-American influence on the development of bioethics remained important and even dominant, certainly also due to the enormous impact of some British centers. This implies that describing bioethics in Europe cannot ignore this overall presence of some AngloAmerican tendencies. My considerations are however much more directed to some typically continental European perspectives, because I am convinced that continental Europe has quite a lot to offer on the table of the intercontinental bioethics dialogue. This may of course also be said about developments in South-America, Asia and Africa.

\section{Historical Evolutions in European Bioethics}

As described in the introduction, the creation of the Barcelona's Institut Borja de Bioètica is certainly one of the earliest developments in European Bioethics. At the same time, fortunately enough, the European dimension of the bioethical debate was stimulated by the creation of the European Association of Centers of Medical Ethics (EACME). F. Abel played an eminent role in this organization. Together with Brussels (J.F. Malherbe and E. Boné), Lyon (N. Léry, the first president), London ( $\mathrm{R}$. Nicholson), Maastricht (M. de Wachter, the second president) and Leuven (P. Schotsmans, the third president), the Barcelona Institute (with F. Abel) developed an international research and communication network. "European" is used in the broad sense of the term, i.e. from the Atlantic to the Urals. The Asso- 
ciation aimed and still aims at promoting public critical concern regarding the ethical issues involved in the development of biomedical sciences in our communities.

Typical for this European network are the different cultures. At this moment, more than 60 centers from all over Europe take part in the Association. One of the advantages of the European network is that it is not closed up in one culture and that the Anglo-American approach does not have a one-sided influence on the development of bioethics. The Germanic, Romanic, and Eastern European culture are developing a "health care ethics" which is therefore rather different from the dominant AngloAmerican mainstream.

Crucially important for the European perspective is the presence of the so-called southern European (or more Romanic) cultures: Spain, Italy, Portugal and France played and still play an important role in the organization. Bioethics is lively and well in these regions of Europe, although the influence of their ethicists on the intercontinental level remains rather weak. This is mainly due to the differences in language and also to the fact that the main bioethics journals are published in English. It is, however, regrettable that it takes so long before this type of European bioethics enters in the intercontinental picture.

In August 1987, the European Society for Philosophy of Medicine and Healthcare (ESPMH) was founded under the stimulating direction of Henk ten Have (presently the Director of the Bioethics Institute of Unesco, but then professor of medical ethics in Nijmegen, Holland) and its first conference was held at Maastricht, the Netherlands, with "The Growth of Medical Knowledge" as its main topic. The ESPMH was instituted by an international company of philosophers, physicians, ethicists and other interested professionals in the field with a view to the growing need for critical reflection on the role of medicine and health care in our present society. They described the background of this network as follows: "Health-related issues increasingly influence the functioning of social security systems (social welfare systems) and demands for health care strain the national budgets of most western countries. In our culture, resulting problems tend to be approached by searching exclusively for technocratic and econometric solutions. Philosophical analysis and ethical evaluations have long been neglected. Recently however, Faculties of Medicine, professional organizations and to a certain extent, the popular mind, have shown an increase in awareness of these deficiencies. New teaching programs and research projects on meta-medical subjects are now being introduced but often meet with strong opposition, if not straightforward obstruction. Thus it seems imperative that these efforts should be strengthened through contacts and cooperation at a European level. The Goals of the ESPMH are threefold: to stimulate and promote the development and methodology in the field of philosophy of medicine and health care; to be a center of contact for European scholars in this field; to promote international contact between members of the various countries in and outside Europe." The best thing they could do, was what they finally did: creating a European journal, namely "Medicine, Health Care and Philosophy. A European Journal" (with the eight volume in 2005). In August 2005, for the first time since their existence, the two groups will meet together in a co-sponsored annual conference in Barcelona, Spain. This may be symbolic for the 'return' to their origins.

Having presented both main networks of bioethics in Europe, I concentrate now on more legal and regulatory bodies. The two most important evolutions on this regulatory level are without any doubt the creation of an advisory 
committee to the European Commission and the publication of the Convention on Human Rights and Biomedicine of the Council of Europe. While the first initiative still stands in the context of an ethics advisory committee, the second initiative is much more important for the future of Europe: it links bio-ethical insights and principles to the European Declaration on the Protection of Human Rights. In that way this Convention levels up ethical reflection to a legal framework. I will give a short description of these two bodies, before making a more content oriented analysis of European bioethics. At the end I will illustrate with statements of the two bodies how bioethical insights framed some of their positions.

The European Group on Ethics in Science and New Technologies is an independent, pluralist and multidisciplinary body which advises the European Commission on ethical aspects of science and new technologies in connection with the preparation and implementation of Community legislation or policies. In December 1997, the European Commission set up the European Group on Ethics (EGE) to succeed the Group of Advisers on the Ethical Implications of Biotechnology. During its first mandate the EGE provided opinions on subjects as diverse as human tissue banking, human embryo research, personal health data in the information society, doping in sport and human stem cell research. At a specific request of the President of the Commission, Romano Prodi, the Group also wrote the Report on the Charter on Fundamental Rights related to technological innovation. On April 24, 2001 the Commission has appointed the twelve Members for the period 2001-2004 (http://europa.eu.int/comm/ european_group_ethics/index_en.htm).

The Council of Europe (41 member states) wished to secure respect of human rights in biomedical research and to harmonize various regu- lations on bioethics in Europe. This initiative was at the origin of the creation of the very first international Convention on Bioethics. In June 1996 the Steering Committee on Bioethics (CDBI) approved the final form of the draft Convention on Human Rights and Bioethics, which was-somewhat unexpectedly-approved by the Parliamentary Assembly, and adopted by the Committee of Ministers in November 1996(1), as the "Convention for the Protection of Human Rights and Dignity of the Human Being with regard to the Application of Biology and Medicine: Convention on Human Rights and Biomedicine" (http://conventions.coe.int/treaty/ en/treaties/html/164.htm).

\section{Bioethics in the European tradition}

Thanks to the Romanic and Germanic influences on the ethos of the practice of medicine, the impact of the Hippocratic tradition is still much more evident in Europe than e.g. in the United States of America. This tradition is essentially functional in the recognition of the physician-patient relationship as foundational for every bioethical discourse. This typically European approach is splendidly presented in a recent report of a research project under the Biomed II Programme of the European Commission. F. Abel and N. Terribas of the Institut Borja de Bioètica have written the introductory presentation: "The objective was to establish a consensus on the formulation of basic ethical principles in bioethics and biolaw. The task has not been easy, but under the leadership of Professor Peter Kemp, Centre for Ethics and Law in Nature and Society, Copenhagen, we believe it has been successful(2)". This excellent report may help us to clarify the mainstreams in the European bioethics tradition ${ }^{2}$.

\footnotetext{
We will therefore refer to this publication by simply mentioning the volume and the pages.
} 


\section{The Concept of Personhood}

The essential difference between American Principlism and European Bioethics is connected with the interpretation of the concept of personhood: "Our European vision of personhood goes further than a minimalist concept of the person, by not only focusing on autonomy but also looking at the concepts of integrity, dignity and vulnerability. Of special interest is the extent to which the basic ethical principles relate to the limits of human existence and lead to a vision of the development of civilized society and the realization of human beings in solidarity and responsibility. We can further argue that human beings at the edges of life should be respected in their "proximity to persons'. Our treatment of them is dependent on cultural understandings of the potential for gaining or regaining self-awareness; the potentialities of becoming a personal being and bonding to significant others or to society at large. The anthropological underpinning of this conception of human being is that respect for the basic ethical principles is used to protect the development of the human character. Thus integrity and dignity are terms which, though not identical, are closely linked (I, 23)".

It is important to notice that the protection of the free development of the human person is very significant in this philosophy. Therefore, existentialist and phenomenological German and French philosophy from the $20^{\text {th }}$ century can offer anthropological premises for understanding the basic ethical principles in relation to the human person. The anthropological foundation has many philosophical mainstreams: E Husserl for Phenomenology; M. Heidegger, M. Scheler, H. Bergson, J.P. Sartre, M. MerleauPonty, A. Camus and many others for Existentialism; M. Buber and E. Levinas for Relational Philosophy; the Frankfurter Schule for Communicative Ethics... It has even developed in a specific approach to medical ethics, linked to the so-called Personalism(3), an approach which is typical for the ethical tradition where I belong to.

\section{The Physician-Patient Relationship}

Typically European remains the interest in the physician-patient relationship as a structural and foundational basis for bioethics. This is probably linked to strong traditions of professional ethics in countries like France, Spain, Germany and Belgium. It is my impression that continental European Bioethics has always entered the field with a clear reference to the basic ethical culture of the medical profession. Even more, European philosophers as M. Buber(4) and E. Levinas(5) -and also P. Ricoeur(6) - have helped to understand in a more fundamental way the basic foundational structure of the medical profession: the medical profession is indeed a relational profession, full of commitment and devotion to the patient $(3, p .13)$. In the Biomed Report we find the following statement: "In recent years there has been a shift from medical paternalism toward respect for the will and wishes of the patient as an independent moral agent. In understanding the relationship between health personnel and patients it is important to distinguish between bioethics and biolaw. This means that a 'friendship model' based on close encounters and prudential relationships between health care personnel and patients precedes the 'contractual rights model' of biolaw (I, 70)".

\section{Solidarity as the Founding Value of European Health Care Systems}

By stressing the value of solidarity European bioethics has always accompanied a socialized model for the development of health care systems. It is important to notice that the idea of European civilization is founded on the ideal of a movement towards social justice, where everyone is respected in his or her hu- 
manity. It is a vision of a collective history towards solidarity and fraternity in the creation of a civilized society where every citizen is protected by the rule of the law. We found a remarkable statement on this subject in the Biomed Report: "We can even say that the welfare state has changed the contractual liberalist understanding of law, based on the social contract. Civil law has changed into social law, leading to a broader conception of state responsibility towards members of society. The sharp distinction between law and morals in traditional civil law has been changed by the development of the welfare state. The ideas of universality, liberty and fraternity are essential principles that govern legal structures in the modern state. Thus, the liberal credo of personal liberty and responsibility related to the specific actions of a free individual has been replaced by state responsibility for the destiny of a citizen (Vol. 1, 60)".

This approach has been responsible for the creation of a solidarity based health care system in Europe, mostly constructed on the idea of collective responsibility. In any case, solidarity implies that the social network is developed in such a way that not only the rich and privileged, but also the poor and the unemployed may enter the health care institutions with an equal access to standard medical treatment. Ruud ter Meulen refers in this context to the notion of "humanitarian solidarity": this kind of solidarity, which is based on the dignity of the human person, wants to protect those human persons whose existence is threatened by circumstances beyond their own control, particularly natural fate or unfair social structures. Humanitarian solidarity should be the starting point for defining necessary care. Care services for persons unable to care for themselves because of psychological handicaps, for example, Alzheimer disease, psychiatric disorders, or mental retardation, should have prior- ity in the basic package. Defined in this way, the basic package should be equally accessible to all, without financial constraints like co-payments or obligatory risks. A two tier system based on the principle of humanitarian solidarity puts care, not cure, at the center of its efforts to provide an adequate level of health care for all(7).

This solidarity based approach is hardly understandable for a liberalist understanding of health care, and as I observed regularly, therefore also almost impossible to understand for an Anglo-American observer. European bioethics applies this approach, however, as a kind of prevention of a too strongly market driven approach in health care. Needless to mention that the enormous costs of the welfare state also create their typical problems, but the issue of the allocation of scarce resources is radically different, if you approach it from the value of solidarity or from a market-driven intention.

\section{The Concept of Human Dignity}

Probably the most important European concept is that of Human Dignity. The anthropological mainstream with strong Germanic and Romanic influences has preserved the concept of "human dignity" in European bioethics and bio-law : "...the issue of dignity is fundamentally one of recognizing the 'abstract nudity of humanity' in every human being. Even bodily decay cannot abolish the appeal to treat everybody as ends-in-themselves with equal dignity. It is this conception of human dignity that has become the foundation of human rights as the legal instruments to protect the human person $[\ldots]$ This also includes the extension of human rights in bio-rights for all ways and kinds of human life. In bioethics the very essence of mankind is at stake. The need to protect human dignity is in particular present at the limits of human life, where the human person can no 
longer be said to have autonomy. This pertains to the dignity of the embryo, the dead body, handicapped newborns etc. (I, 37)".

The ethical clarification of the concept of Human Dignity remains also in Europe a subject of strong debate. It is therefore interesting to see how the Biomed Report tried to make a synthesis:

"Although we must admit that there are great disagreements concerning the adequate understanding of human dignity, a substantial content of the concept can be summed up in the following steps (I, 35):

1. Human dignity emerges as a virtue of recognition of the other in an intersubjective relationship. This recognition is based on social construction. As a social concept human dignity constitutes a capacity that the person has because of his or her social position.

2. Dignity is universalized and indicates the intrinsic value and moral responsibility of every human being.

3. The person must, as a result of the intersubjective understanding of dignity, be considered as without a price. Therefore, human beings cannot be objects for trade or commercial transaction.

4. Dignity is based on self-other relations of shame and proudness, e.g. in degradation and self-esteem.

5. Dignity defines certain 'taboo' situations and emotions as the limits of civilized behavior. This means that there are certain things that a society should just not do.

6. In this way dignity emerges in the process of human civilization.
7. Finally, dignity includes the individual's openness to the metaphysical dimensions of life, referring to dignified behavior at the limit-situations of existence such as birth, suffering, death of a beloved other, one's own death etc."

This concept of human dignity is predominantly present in the Convention on Human Rights and Biomedicine of the Council of Europe (1996). The main purpose of the Convention has been the protection of human dignity for present and future generations. It is typical for the European approach that some observers still are convinced that this concept is not enough related to the phenomenological or personalistic foundation of law: " Instead of focusing on self-determination the Convention on Human Rights and Biomedicine should accept the full consequences of its anthropological presuppositions, and found respect for the body of the human being in the notions of integrity and dignity in order to make a clear formulation of a philosophy of the human body and the whole living world $(\mathrm{I}, 301)^{3}$ ".

\section{The Functioning of Bioethics}

Principlism(8) has led to an approach which is more or less procedural: one of the weaknesses of this approach is clearly that it may be possible to develop a line of Principlist reasoning without being aware what we understand under what is good or not good. In contrast with this approach, European bioethics has always been much more "teleological" in character: the willingness to realize the humanly desirable (as the 'telos' or goal of our actions) is the driving force in many European ethical approaches. This implies that the concept of personhood functions as a clarification of the humanly desirable (cf. P. Ricoeur): the promotion of the

Vol. I, p. 301: the Editors of this volume refer to their personal critical remarks on the Convention. 
human person in all his dimensions and relationships is indeed the dynamic factor in the development of an ethical reasoning. This personalist self-understanding of European bioethics at the same time explains the importance of the concept of personhood, human dignity, responsibility and solidarity, all basic dimensions of the humanly desirable. Ethical reasoning is therefore fundamentally normative and remains challenged by the clarification of the basic goods.

\section{The European Contribution}

Presenting European bioethics implies at the same time partly a radical critique on the Principlist approach: the "Georgetown mantra" lacks a sound ethical basis to function adequately for consistent ethical decision making. This is not something new: European medical ethicists (especially those who belonged to the Germanic and Romanic cultures) remained from the early beginnings of the breakthrough of bioethics very reluctant to integrate Principlism into their ethical reflection. For the majority of the continental European approach to bioethics, the influence of the philosophical and anthropological mainstreams in the European tradition urged to a more foundational approach to bioethics: phenomenology and existentialism as an historical background to understand the vulnerable patient and the medical profession; relational philosophy to clarify the physician-patient relationship; solidarity and social justice theories as a framework for the welfare state.

These inspirational traditions keep their force and make bioethics much more than a method for medical decision making. They help to promote an ethical culture in medicine for the reason that they situate bioethics where it really belongs: in the heart and the middle of the relationship between the physician and the vulnerable patient. European bioethics wants to serve this culture of medicine and should therefore have a much more influential place in the intercontinental dialogue than it has until now.

\section{Regulatory and Legal Initiatives}

I present now shortly two short illustrations of European regulatory approaches to developments in biomedicine. The first one is the opinion of the EGE on human stem cell research; the second one is the additional protocol on organ transplantation by the Council of Europe.

\section{The EGE on human stem cell research}

It is quite remarkable how quickly international organizations have dismissed the possibility of reproductive human cloning. However, the decision of the British Parliament (with the vote in the House of Lords on January 23rd, 2001) to allow therapeutic cloning indicates a rather moderate attitude. A select committee of the UK House of Lords decided to allow scientists in the UK to create and carry out research on human embryo clones. Licenses for the use of cloned embryos, however, should only be granted if there is a demonstrable and exceptional need that cannot be met by using spare embryos after an IVF-treatment. ${ }^{4}$ Several countries of the European mainland also took position on stem cell research and therapeutic cloning. France and the Netherlands, for example, introduced a bill in Parliament, opposing the creation of embryos solely for research purposes. Embryos derived from IVF, on the other hand, which are no longer required for a parental project become available for stem cell research. As for Germany, the National Ethics Committee circumvented the rigorous 'embryo-

\footnotetext{
4 House of Lords. Stem Cell Research-Report. 13 February 2002. [Website] Available in http://www.parliament.thestationery-office.co.uk
} 
law' by deciding to recommend allowing the import of human stem cells from abroad under clear supervision.

All this makes clear that policy makers are rather reticent about reproductive cloning but that there is a more open attitude to stem cell research and even towards therapeutic cloning. The European Parliament has explicitly rejected a move to ban human therapeutic cloning in the European Union. Only 37 of the 391 EuroMPs voted in favor of the 'Fiori report' on the social, legal, ethical and economic implications of human genetics (November 29 ${ }^{\text {th }}, 2001$ ). Similar voices could be heard at the conference of the Life Sciences High Level Group of the European Commission, entitled Stem Cells: Therapies for the Future (19 December 2001) ${ }^{5}$. The opinion of the European Group on Ethics in Science and New Technologies, addressed to the European Commission, prohibits therapeutic cloning, but then again allows stem cell research on 'spare' embryos ${ }^{6}$. In the opinion of the Group, in such a highly sensitive matter, "the proportionality principle and a precautionary approach must be applied: it is not sufficient to consider the legitimacy of the pursued aim of alleviating human sufferings, it is also essential to consider the means employed. In particular, the hopes of regenerative medicine are still very speculative and debated among scientists. Calling for prudence, the Group considers that, at present, the creation of embryos by somatic cell nuclear transfer for research on stem cell therapy would be premature, since there is a wide field of research to be carried out with alternative sources of human stem cells (from spare embryos, foetal tissues and adult stem cells) (Opinion $\mathrm{N}^{\circ} 15$ ).

Conference videos and papers can be consulted at http:// europa.eu.int/comm/research/quality-of-life/stemcells.html European Group on Ethics in Science and New Technologies. Adoption of an Opinion on Ethical Aspects of Human Stem Cell Research and Use. 14 November 2000, revised edition, January 2001.

\section{The Council of Europe on Organ Transplantation}

The original Convention (1996) devoted the sixth Chapter to "organ and tissue removal from living donors for transplantation purposes". It was a surprise that no orientation was given for cadaver donors. This was corrected by an "Additional Protocol to the Convention on Human Rights and Biomedicine, on Transplantation of Organs and Tissues of Human Origin" (Strasbourg, 24 January 2002). The Protocol remains very general and allows the co-existence of several consent procedures, like the "opting in" and "opting out" system. In Article 17, this is mentioned as follows: "Organs or tissues shall not be removed from the body of a deceased person unless consent or authorization required by law has been obtained. The removal shall not be carried out if the deceased person has objected to it".

More important is however the prohibition of financial gain, as described in Chapter VI: "The human body and its parts shall not, as such, give rise to financial gain or comparable advantage [...] Organ and tissue trafficking shall be prohibited".

\section{Conclusion}

The continental European approach to bioethics is multifaceted. The respect for the dignity of the human person in his relational and societal involvement is much more dominant than it is in the Anglo-American approaches to bioethics. This is also translated in the regulatory and legal systems of the different European bodies. I presented the European Group on Ethics, with its moderate view on human stem cell research, and the - more important - European Convention on Human Rights and Biomedicine. I do express therefore a sincere hope that bioethics may always and everywhere integrate this manysided approaches to medicine and health care. 


\section{References}

1. De Wachter MAM. The European Convention on Bioethics. Hastings Center Report 1997; 27 (1): 13-23.

2. Rendtorff JD, Kemp P, (eds.) Basic Ethical Principles in European Bioethics and Biolaw. Vol. I. Autonomy, Dignity, Integrity and Vulnerability. Copenhagen- Barcelona: Centre for Ethics and Law and Institut Borja de Bioètica; 2000: 11.

3. Schotsmans P. Personalism in Medical Ethics. Ethical Perspectives 1999; 6: 10-19.

4. Buber M. Ich und Du. Leipzig: Im Insel-Verlag; 1923.

5. Levinas E. Autrement qu'être ou au-delà de l'essence. La Haye: Martinus Nijhoff; 1974.

6. Ricoeur P. Le problème du fondement de la morale. Sapienza 1975 ; 28: 313-337.

7. Ter Meulen R. Are There Limits to Solidarity with the Elderly? Hastings Center Report 1994; 25(5): 36-38.

8. Beauchamp TL, Childress JF. Principles of Biomedical Ethics. New York: Oxford Press; 2001. 